\title{
Characterization of Catalase by Micro-Immunoprecipitation in Tissue-Derived Cells of Mycobacterium lepraemurium TMC 1701
}

\author{
V. M. KATOCH, ${ }^{1}$ L. G. WAYNE, ${ }^{1,2}$ AND G. A. DIAZ ${ }^{1}$ \\ Tuberculosis Research Laboratory, Veterans Administration Medical Center, Long Beach, California $90822^{1}$ \\ and Department of Medical Microbiology, California College of Medicine, University of California at Irvine, \\ Irvine, California $92664^{2}$
}

\begin{abstract}
Cell-free extracts of tissue-derived cells of Mycobacterium lepraemurium TMC 1701 have been found to have mycobacterial catalase which is of the T type. Immunological distance measurements of this catalase against three reference mycobacterial systems, as determined by a micro-immunoprecipitation technique, showed that catalase from $M$. lepraemurium TMC 1701 is most closely related to that of Mycobacterium avium but is still distinct from it. In this respect, this strain is uniquely positioned between Mycobacterium tuberculosis and $M$. avium.
\end{abstract}

Mycobacterial catalases have been broadly grouped into two major classes, $\mathrm{T}$ and $\mathrm{M}(10)$, depending upon their physical properties, susceptibility to various inhibitors, and kinetics of activity $(1,2,10)$. In earlier studies (8-10), measurement of the differences in their serological specifications has proven to be a useful tool for taxonomic or (indirectly) evolutionary studies of mycobacteria. Immunological distance correlates well with the structural divergence of proteins having substitutions of up to about $40 \%$ of the component amino acids (4). However, studies on tissue-derived mycobacteria are difficult because of low yields of organisms as well as contamination with host enzymes (11). Previous studies $(3,5)$ have described the presence of peroxidase in the Antwerp strain of Mycobacterium lepraemurium grown in vivo and of catalase in Keishicho-strain cells grown in vitro. This study was undertaken to confirm the mycobacterial origin of the catalase present in tissuederived $\boldsymbol{M}$. lepraemurium TMC 1701 suspensions and also to evaluate its taxonomic importance.

\section{MATERIALS AND METHODS}

The strain of $M$. lepraemurium used in this study was the Hawaiian strain (TMC 1701) grown in ABG6 hybrid mice (supplied from the Trudeau Institute Inc., Saranac Lake, N.Y.). Cells were harvested and purified by the method of P. Draper (personal communication). The two-polymer aqueous-phase system consisted of $0.50 \mathrm{~g}$ of $1 \%$ polyethylene glycol palmitate (supplied by the National Institute of Medical Research, London), $0.245 \mathrm{~g}$ of polyethylene glycol 6000 (Union Carbide Corp., New York, N.Y.; recently named 8000), $0.35 \mathrm{~g}$ of Dextran T500 (Pharmacia Fine Chemicals, Piscataway, N.J.; lot no. 11648), $0.025 \mathrm{ml}$ of $2 \mathrm{M} \mathrm{NaCl}, 0.10 \mathrm{ml}$ of $0.05 \mathrm{M}$ phosphate buffer $(\mathrm{pH}$ 6.9), and $3.28 \mathrm{ml}$ of distilled water; this was sufficient to purify $0.2 \mathrm{ml}$ of packed bacterial cells in the final stages of purification. The cells were suspended in low-salt buffer and were sonicated by a method described previously (2). Sonic extracts were added to a suspension of DEAE-cellulose (Sigma Chemical Co., St. Louis, Mo.) and were washed in low-salt buffer; the product was then eluted in $0.5 \mathrm{M} \mathrm{NaCl}$ for use in this study (9).

The catalase preparation was first assayed both in the presence and the absence of 3-amino-1,2,4-triazole (AT). Equal volumes of catalase preparation and AT (final concentration, $10 \mathrm{mg} / \mathrm{ml}$ ) were incubated at $37^{\circ} \mathrm{C}$ for $2 \mathrm{~h}$ and then were analyzed for catalase activity by the zero-order $\mathrm{TiCl}_{4}$ assay of residual $\mathrm{H}_{2} \mathrm{O}_{2}$ as described previously (10).

Untreated cell-free extracts were then incubated with serial dilutions of reference sera specific for mycobacterial catalases from different mycobacterial species, and the unreacted catalase was assayed by a microenzyme titration technique which is a modification of the method described earlier (9). Briefly, $10 \mu \mathrm{l}$ of catalase preparation $(0.01 \mathrm{U})$ was mixed with $10 \mu \mathrm{l}$ of each of the serum dilutions in polyethylene centrifuge tubes and was incubated at $37^{\circ} \mathrm{C}$ for $1 \mathrm{~h}$, followed by overnight incubation at $5^{\circ} \mathrm{C}$. The contents were then drawn into 20- $\mu$ l microcapillary tubes (Corning Glass Works, Corning, N.Y.; catalog no. 70995-20). The lower ends of these capillary tubes were sealed with putty and the tubes were then centrifuged at 900 $\times g$ for $20 \mathrm{~min}$. The capillary tubes were cut at a distance from the meniscus corresponding to $15 \mu \mathrm{l}$ of contents, and this supernatant was discharged and analyzed for catalase as described earlier (9), except that the volumes of $\mathrm{H}_{2} \mathrm{O}_{2}$ and titanium tetrachloridesulfuric acid used were reduced proportionately. The first-order calculations of the $T$ catalase activity and immunological distance were based upon earlier publications (8-10). The reference antisera to $T$ catalases were prepared as also described previously $(8-10)$; the 
sera included in the study were RS 75-32726 (antiMycobacterium avium TMC 716 catalase), RS 11430180 (anti-Mycobacterium kansasii TMC 1201 catalase), and RS 120-10381 (anti-Mycobacterium tuberculosis $\mathrm{H}_{37} \mathrm{Rv}$ catalase). The micro method was compared with the standard method (9) and was found to give comparable immunological distances for several mycobacterial catalase titration systems.

\section{RESULTS}

It was found that AT had no significant effect on catalase activity in the cell-free preparation of $M$. lepraemurium sonicates; the mean changes in absorbance at $410 \mathrm{~nm}$ observed in the assays were 0.200 and 0.204 with and without AT treatment, respectively. This resistance to AT indicated that the catalase in the preparation was of the $T$ type and that there was no significant M-type catalase activity, either of host or bacterial origin, in these sonicates.

The immunological distance experiments (Table 1) revealed that the catalase from $M$. lepraemurium TMC 1701 preparations was most closely related to $M$. avium catalase. The standard and micro methods showed a good correlation, the immunological distance between $M$. avium and $M$. lepraemurium TMC 1701 being $24 \pm 4$ by the standard method and $24 \pm 6$ by the micro method. It was found that the $M$. lepraemurium TMC 1701 catalase was positioned between those of $M$. avium and $M$. tuberculosis and was quite distant from that of $M$. kansasii. That is, the sum of the distances from $M$. lepraemurium TMC 1701 to $M$. tuberculosis and to M. avium is almost identical to the reciprocal distances between $M$. avium and $M$. tuberculosis reported previously (9). Furthermore, the relative distances seen among three reference systems exhibited a high order of complementarity to the relative values previously reported between these three reference systems $(8-10)$. This zeroorder micro technique required only $0.01 \mathrm{U}$ per test as compared with $0.05 \mathrm{U}$ per test by the zero-order standard method (8) or $0.5 \mathrm{U}$ per test by the first-order macro method used in the earliest studies (2).

\section{DISCUSSION}

Stanford (6) noted a marked similarity between $M$. avium and $M$. lepraemurium strains in terms of numbers of shared antigens as determined by immunodiffusion, and Stanford and Grange later (7) suggested that $M$. lepraemurium should be recognized as a subspecies of $M$. avium. The present study, with a different parameter, supports the findings of Stanford (6) that $M$. lepraemurium is more closely related to $M$. avium than to any other species tested, but there does appear to be a distinct immunological distance between catalases of the two species.
TABLE 1. Immunological distances of $T$ catalase of $M$. lepraemurium TMC 1701 from three standard T catalase reference systems

\begin{tabular}{lccc}
\hline & \multicolumn{3}{c}{ Immunological distances from: ${ }^{a}$} \\
\cline { 2 - 4 } Strain tested & $\begin{array}{c}M . \\
\text { tuberculosis } \\
\mathrm{H}_{37} \mathrm{Rv}\end{array}$ & $\begin{array}{c}M . \text { avium } \\
\text { TMC 716 }\end{array}$ & $\begin{array}{c}M . \\
\text { kansasii } \\
\text { TMC 1201 }\end{array}$ \\
\hline $\begin{array}{l}\text { M. tuberculosis } \\
\text { H }\end{array}$ & & $(97 \pm 5)$ & $(145 \pm 9)$ \\
$\begin{array}{l}\text { M. lepraemurium } \\
\text { TMC 1701 }\end{array}$ & $68 \pm 8$ & $24 \pm 6$ & $70 \pm 6$ \\
$\begin{array}{l}\text { M. avium TMC } \\
\text { 716 }\end{array}$ & $(98 \pm 6)$ & & $(15 \pm 7)$ \\
$\begin{array}{l}M \text {. kansasii } \\
\text { TMC 1201 }\end{array}$ & $(143 \pm 16)$ & $(29 \pm 3)$ & \\
\hline
\end{tabular}

${ }^{a}$ Values show immunological distance \pm standard deviation (3 replications). Numbers in parentheses are data from previously published studies $(8-10)$.

In a previous study, Wayne and Diaz suggested a correlation between the position of species on a diagram of divergence of their $T$ catalases and the evolution of these species in terms of their saprophytic and pathogenic natures (10). In the present study, catalase from $M$. lepraemurium TMC 1701 was found to be uniquely positioned between those of $M$. avium and $M$. tuberculosis, providing further support for a correlation between the evolution of species and their pathogenicity. So far, no other mycobacterial species have been described to be positioned like this on the scale of divergence.

It can be concluded from the present study that the catalase detected in $M$. lepraemurium TMC 1701 preparations is a mycobacterial $\mathrm{T}$ catalase rather than a host enzyme and that it has a position between the catalases of $M$. avium and $M$. tuberculosis. Furthermore, the facts that this micro technique needs 5 times less enzyme than the semimicro standard technique (8) and 50 times less enzyme than the macro method (2) and is equally sensitive and specific make it highly suitable where a very small amount of material, e.g., tissue-derived bacteria, is available. Thus, in this study five mice yielded about $0.5 \mathrm{ml}$ of packed cells of $M$. lepraemurium TMC 1701 and enough mycobacterial catalase for about 50 serum titrations. This kind of serological approach may be useful for studying other enzyme systems as well.

\section{ACKNOWLEDGMENTS}

The authors thank F. M. Collins and P. J. Patel (Trudeau Institute Inc.) for providing a culture of $\boldsymbol{M}$. lepraemurium TMC 1701; we thank Philip Draper (National Institute of Medical Research, London) for advice on purifying the mycobacterial cells.

V.M.K. was working as an International Tropical Disease Research Fellow of the National Institutes of Health (grant no. 1 FO5 TWO2973-01) on sabbatical leave from Central JALMA Institute for Leprosy, Agra, India. 


\section{REPRINT REQUESTS}

Address reprint requests to: Dr. L. G. Wayne, Veterans Administration Medical Center (151), Long Beach, CA 90822.

\section{LITERATURE CITED}

1. Bartholomew, R. 1968. Multiple catalase enzymes in two species of mycobacteria. Am. Rev. Respir. Dis. 97:710712.

2. Diaz, G. A., and L. G. Wayne. 1974. Isolation and characterization of catalase produced by Mycobacterium tuberculosis. Am. Rev. Respir. Dis. 110:312-319.

3. Jacob, W., S. R. Pattyn, and P. Dockx. 1977. Cytochemical evidence for aerobic pathways in Mycobacterium lepraemurium. Int. J. Lepr. 45:9-13.

4. Prager, E. M., and A. C. Wilson. 1971. The dependence of immunological cross-reactivity upon sequence resemblance among lysozymes. J. Biol. Chem. 266:5978-5989.

5. Saito, H., K. Yamaoka, and K. Kiyotani. 1976. In vitro properties of Mycobacterium lepraemurium strain Keishicho. Int. J. Syst. Bacteriol. 26:111-115.
6. Stanford, J. L. 1973. An immunodiffusion analysis of Mycobacterium lepraemurium Marchoux and Sorel. J. Med. Microbiol. 6:435-439.

7. Stanford, J. L., and J. M. Grange. 1974. The meaning and structure of species as applied to mycobacteria. Tubercle 55:143-152.

8. Wayne, L. G., and G. A. Diaz. 1976. Immunoprecipitation studies of mycobacterial catalase. Int. J. Syst. Bacteriol. 26:38-44.

9. Wayne, L. G., and G. A. Diaz. 1979. Reciprocal immunological distances of catalase derived from strains of $\mathrm{Myco-}$ bacterium avium, Mycobacterium tuberculosis, and closely related species. Int. J. Syst. Bacteriol. 29:19-24.

10. Wayne, L. G., and G. A. Diaz. 1982. Serological, taxonomic, and kinetic studies of the $T$ and $M$ classes of mycobacterial catalase. Int. J. Syst. Bacteriol. 32:296304 .

11. Wheeler, P. R., and D. Gregory. 1980. Superoxide dismutase, peroxidatic activity and catalase in Mycobacterium leprae purified from armadillo liver. J. Gen. Microbiol. 121:457-464. 